\title{
PENGARUH PENGETAHUAN AWAL AKUNTANSI DAN EFIKASI DIRI TERHADAP TINGKAT PEMAHAMAN AKUNTANSI MELALUI MINAT BELAJAR PADA MAHASISWA JURUSAN AKUNTANSI UNIVERSITAS PGRI ADI BUANA SURABAYA
}

\author{
Mohammad Taufiq, Universitas Negeri Surabaya \\ cakupeq@gmail.com
}

\begin{abstract}
ABSTRAK
Penelitian ini dilakukan untuk menganalisis pengaruh pengetahuan awal akuntansi, efikasi diri, dan minat belajar terhadap tingkat pemahaman akuntansi mahasiswa jurusan akuntansi Universitas PGRI Adi Buana Surabaya. Pendekatan yang digunakan dalam penelitian ini adalah kuantitatif. Populasi adalah mahasiswa semester 2 angkatan 2014/2015 Jurusan Akuntansi Fakultas Ekonomi Universitas PGRI Adi Buana dengan sampel sebanyak 156 mahasiswa. Teknik analisis data menggunakan Structural Equation Modelling (SEM).Hasil penelitian menunjukkan bahwa ada pengaruh signifikan pengetahuan awal akuntansi dan efikasi diri terhadap minat belajar, dan pengaruh minat belajar terhadap tingkat pemahaman akuntansi.

Kata Kunci :Pengetahuan Awal Akuntansi, Efikasi Diri, Minat Belajar, Tingkat Pemahaman Akuntansi
\end{abstract}

\begin{abstract}
This study was conducted to analyze the effect of accounting prior knowledge, self-efficacy, and interest in the level of understanding of accounting majors accounting PGRI Adi Buana University of Surabaya. The approach used in this research is quantitative. Populations are the second semester students 2014/2015 Accounting Department of Economics, PGRI Adi Buana University with a sample of 156 students. Data were analyzed using Structural Equation Modeling (SEM). The results showed that there was a significant effect of prior knowledge of accounting and self efficacy on the interest in learning, and learning interest influencing the level of understanding.

Keywords: prior knowledge, self efficacy, learning interest, understanding of accounting
\end{abstract}

\section{PENDAHULUAN}

Perguruan tinggi sebagai institusi pendidikan turut berperan aktif dalam menghasilkan lulusan yang berkualitas dan mampu berkontribusi bagi masyarakat di sekitarnya. Khusus mengenai pendidikan dalam bidang akuntansi, perguruan tinggi dituntut untuk mencetak calon akuntan yang memiliki integritas selain juga mampu bersaing pada kompetisi dunia kerja yang semakin ketat, untuk itulah proses belajar-mengajar di perguruan tinggi menjadi sesuatu yang penting.

Proses belajar-mengajar di perguruan tinggi sesuai dengan Permendikbud Nomor 49 Tahun 2014 disebutkan bahwa terdapat dua tujuan yang saling menunjang, yakni tujuan lembaga pendidikan dalam menyediakan sumber pengetahuan dan pengalaman belajar serta tujuan individual yang menjadi 
kebutuhan pribadi mahasiswa. Adapun Penyelenggaraan dan pengembangan pendidikan akuntansi di perguruan tinggi dibawah undang-undang No.12 Tahun 2012 Tentang Pendidikan Tinggi, dimana perguruan tinggi harus mengarahkan mahasiswanya untuk penguasaan dan pengembangan cabang ilmu pengetahuan dan teknologi dalam hal ini adalah cabang ilmu pengetahuan akuntansi.

Menurut pendapat Suwardjono (2001) bahwa Pengetahuan terhadap ilmu akuntansi dapat dipandang dari dua sisi pengertian yaitu pengetahuan profesi (keahlian) yang dipraktekan di dunia nyata dan sekaligus sebagai suatu disiplin pengetahuan yang diajarkan di perguruan tinggi. Oleh karena itulah pemahaman tentang keakuntansian mutlak diperlukan seorang mahasiswa untuk melengkapi keilmuan yang sedang ditempuh di perguruan tinggi.

Menurut Suhardian (2012) jurusan akuntansi merupakan salah satu jurusan di fakultas ekonomi Universitas PGRI Adi Buana Surabaya yang banyak diminati oleh mahasiswa. Dari hasil penelitian Ariani (2004) menyebutkan bahwa rata-rata mahasiswa memilih jurusan akuntansi, didorong oleh keinginan mereka untuk menjadi profesional di bidang akuntansi, juga didorong oleh tingginya permintaan profesi akuntan bagin perusahaan di Indonesia.

Pembelajaran mengenai akuntansi salah satunya dilaksanakan pada Universitas PGRI Adi Buana Surabaya (UNIPA) sebagai salah satu perguruan tinggi di Surabaya yang memiliki Jurusan Akuntansi. Pembelajaran di dalam jurusan akuntansi menurut Subroto (2013) menjelaskan bahwa pengajaran akuntansi merupakan metode atau bentuk yang digunakan untuk menyampaikan suatu informasi materi akuntansi kepada mahasiswa. Adapun Kurikulum program pendidikan Strata-1 (S1) Jurusan Akuntansi Fakultas Ekonomi Universitas PGRI Adi Buana Surabaya dikelompokkan sebagai berikut: Mata Kuliah Pengembangan Kepribadian, Mata Kuliah Keilmuan dan Ketrampilan, Mata Kuliah Keahlian Berkarya, Mata Kuliah Perilaku Berkarya, dan Mata Kuliah Berkehidupan Bersama.

Dalam kegiatan belajar mengajar akuntansi di perguruan tinggi, pengetahuan awal mengenai materi akuntansi yang disampaikan oleh pendidik menjadi penting bagi keberhasilan belajar peserta didik dalam materi tersebut. Pandangan tersebut didukung oleh penelitian Handayani (2014) yang menyebutkan bahwa pengetahuan awal berpengaruh positif terhadap hasil belajar peserta didik. Pengetahuan awal materi akuntansi bagi mahasiswa dapat diperoleh dari pengetahuan mahasiswa saat belajar pada proses pembelajaran jenjang sebelumnya atau setingkat SMA sederajat. Di samping dari pengetahuan, pengetahuan awal juga berasal dari sikap dan pengalaman yang telah dimiliki mahasiswa selama belajar. Hal tersebut sejalan dengan pendapat Kujawa dan Huske (2003) menyatakan bahwa pengetahuan awal tidak hanya berkaitan dengan pengetahuan saja, tetapi juga menyangkut sikap dan pengalaman mahasiswa. Pengetahuan tidak hanya terkait dengan pengetahuan teoritis mengenai materi akuntansi, akan tetapi juga disertai dengan sikap diri serta dilengkapi dengan pengalaman baik yang diperoleh dari lingkungan keluarga, teman sebaya, maupun lingkungan belajar di universitas.

Menurut Santyasa (2005), pengetahuan awal berpengaruh secara langsung dan tak langsung dalam proses pembelajaran. Pengaruh secara langsung yang dimaksud adalah pengetahuan awal dapat mempermudah proses pembelajaran dan 
mengarahkan hasil-hasil belajar yang lebih baik. Sedangkan pengaruh tidak langsung, bahwa pengetahuan awal dapat mengoptimalkan kejelasan materi pelajaran dan meningkatkan efisiensi penggunaan waktu belajar dan pembelajaran. Pengetahuan awal dapat mengoptimalkan daya tangkap peserta didik terhadap materi pembelajaran akuntansi yang diperoleh. Selain itu, pengetahuan awal mempengaruhi perasaan peserta didik dalam menilai informasi yang dipresentasikan dalam sumber-sumber belajar di dalam kelas. Model pembelajaran tidak dapat berjalan dengan sempurna apabila tidak disertai dengan perhatian pada pengetahuan awal peserta didik.

Pengetahuan awal yang dimaksud dalam penelitian ini adalah pemahaman tentang akuntansi yang diperoleh mahasiswa jurusan akuntansi yang didapat saat mereka menempuh pendidikan pada jenjang sebelumnya, baik itu di Sekolah Menengah Kejuruan Akuntansi ataupun Sekolah Menengah Atas sederajat. Kemampuan dasar yang dimiliki peserta didik yang diperoleh pada saat belajar di jenjang SMK maupun SMA dapat dijadikan tolak ukur untuk menilai pemahaman belajar akuntansi dan keberhasilan belajar saat peserta didik menempuh mata kuliah akuntansi di perguruan tinggi.

Pada semester awal, setiap perguruan tinggi mewajibkan mahasiswa jurusan akuntansi untuk mengikuti pembelajaran mata kuliah pengantar akuntansi. Sebagai matakuliah yang diajarkan pada semester pertama ditahun pertama, tidak disangsikan lagi mata kuliah pengantar akuntansi memegang peranan penting dan menentukan dalam mengantarkan mahasiswa yang akan mempelajari akuntansi dan matakuliah lain yang berkaitan pada tahapan berikutnya. Sebagai mata kuliah pengantar, mata kuliah ini dimaksudkan untuk memberikan pengetahuan dasar atau fundamental kepada para mahasiswa. Oleh karena itu, konstruk pengetahuan akuntansi yang dimiliki mahasiswa kelak akan banyak dipengaruhi oleh keberhasilan pembelajaran mata kuliah pengantar akuntansi sebagai fondasi dasarnya. Berdasarkan dari pemahaman inilah, penelitian ini lebih spesifik mencoba mengaitkan antara kontribusi pengetahuan awal akuntansi yang diperoleh peserta didik saat duduk di bangku sekolah dengan pemahaman tentang materi mata kuliah pengantar akuntansi saat berada di bangku perguruan tinggi.

Selain pengetahuan awal mengenai materi akuntansi, efikasi diri memiliki pengaruh yang baik dalam menentukan keberhasilan belajar yang akan dicapai oleh peserta didik, karena dengan efikasi diri yang tinggi akan memberikan inisiatif dan ketekunan untuk meningkatkan usaha dan kemampuan seorang untuk mendapatkan apa yang diinginkannya. Taylor (2009) mengatakan bahwa self efficacy merupakan ekspetasi spesifik yang kita yakini tentang kemampuan kita dalam mencapai sesuatu atau mengerjakan tugas. Keyakinan atas suatu hal tersebut dapat terwujud dalam magnitude atau keyakinan untuk menyelesaikan tugas yang dianggap sulit, kemudian generality atau keyakinan dalam menyelesaikan segala variasi tugas, serta strengthatau keyakinan akan kemampuan untuk menyelesaikan tugas. Hal tersebut juga sesuai dengan pendapat yang dikemukakan oleh Adicondro (2011) mengatakan jika seseorang memiliki efikasi diri yang tingi maka akan memiliki keyakinan mengenai kemampuannya dalam mengorganisasi dan menyelesaikan suatu tugas belajar yang diperlukan untuk mencapai hasil belajar tertentu dalam berbagai bentuk dan tingkat kesulitan. Sebaliknya jika seseorang dengan efikasi diri yang rendah akan sangat mempengaruhi seseorang dalam menyelesaikan tugasnya untuk mencapai hasil tertentu. Adicondro (2011) juga 
mengemukakan bahwa efikasi diri sangat menentukan seberapa besar keyakinan mengenai kemampuan yang dimiliki oleh setiapi ndividu untuk melakukan proses belajarnya sehingga dapat mencapai hasil belajar yang optimal.

Disamping pengetahuan awal dan efikasi diri, minat belajar juga merupakan salah satu factor yang ikut menentukan keberhasilan seseorang baik dalam hal studi baik dalam pembelajaran akuntansi maupun bidang yang lain. Banyak ahli yang mengemukakan pendapatnya mengenai minat yang berbedabeda, namun pada dasarnya semua itu merupakan pendapat yang saling melengkapi satu sama lain. Minat merupakan kecenderungan yang menetap untuk memperhatikan dan mengenang beberapa aktifitas (Djamarah, 2002). Sedangkan menurut pendapat Slameto (2010) dalam Indriyanti dkk (2013) mengemukakan, bahwa minat adalah suatu rasa lebih suka dan rasa keterikatan pada suatu hal atau aktivitas, tanpa ada yang menyuruh. Seseorang yang berminat terhadap suatu aktivitas akan memperhatikan aktivitas yang dilakukannya secara konsisten dengan rasa senang. Berarti dari hal tersebut disimpulkan bahwa minat berkaitan dengan rasa lebih suka dan rasa ketertarikan pada suatu hal atau aktivitas tanpa ada yang menyuruh dan pada dasarnya merupakan penerimaan akan suatu hubungan antara diri sendiri dengan sesuatu diluar diri. Dalam hal ini, rasa suka yang dimaksudkan adalah perasaan menyenangi dan tanpa adanya paksaan dari luar dalam diri peserta didik untuk menempuh mata kuliah pengantar akuntansi.

Minat pada dasarnya adalah penerimaan akan suatu hubungan antara diri sendiri dengan sesuatu di luar diri. Semakin kuat atau dekat hubungan tersebut, semakin besar minat yang muncul. Minat dapat dipengaruhi oleh berbagai faktor baik yang berasal dari dalam diri maupun dari luar diri. Minat belajar berperan penting dalam mendorong peserta didik untuk mencapai tujuannya pemahaman mengenai materi pengantar akuntansi yang diajarkan. Mahasiswa yang memiliki minat tinggi ia akan lebih cenderung memilih untuk dengan sukarela atas dasar kesukaannya akan belajar pengantar akuntansi meskipun tanpa ada dorongan dari pihak luar. Sebagai dugaan awal pada mahasiswa jurusan akuntansi Universitas PGRI Adi Buana Surabaya terdapat minat yang cukup tinggi, hal tersebut dalam dilihat saat penerimaan mahasiswa baru mereka manjadikan jurusan akuntansi menjadi pilihan prioritas. Di samping itu, kuota pendaftar pada jurusan akuntansi juga terbilang cukup tinggi dibanding dengan jurusan lain pada fakultas yang sama untuk Tahun Akademik 2014/2015.

Pendidikan akuntansi yang diselenggarakan diperguruan tinggi ditujukan untuk mendidik mahasiswa agar memiliki kompetensi sebagai seorang akuntan profesional. Untuk dapat menghasilkan lulusan yang berkualitas maka perguruan tinggi harus terus meningkatkan kualitas pada system pendidikannya, Mawardi (2011).

Menurut Hariyoga dan Edi (2011) pengetahuan yang dibutuhkan untuk akuntan terdiri dari pengetahuan umum, organisasi, bisnis, dan akuntansi. Pengetahuan tentang dasar-dasar akuntansi merupakan kunci utama untuk memahami ilmu akuntansi. Dasar-dasar akuntansi ini dipakai sebagai pegangan untuk memahami semua praktik dan teori akuntansi. Namun, kenyataannya pendidikan akuntansi yang selama ini diajarkan diperguruan tinggi hanya terkesan sebagai pengetahuan yang berorientasi pada mekanisme secara umum saja, sangat berbeda apabila dibandingkan dengan praktik sesungguhnya yang 
dihadapi di dunia kerja. Masalah tersebut tentu saja membingungkan lulusan akuntansi karena pemahaman akuntansi dibangku kuliah ternyata berbeda dengan dunia kerja.

Sedangkan Dwirandra (2013) menjelaskan bahwakalanganpengusaha dan industriawan tidak hanya meragukan kompetensi akuntan tetapi juga sikap etisnya. Keraguan terhadap kompetensi akuntan didasarkan pada kenyataan adanya beberapa kejahatan korperasi besar dan mendunia yang mengaitkan profesi ini. Selain masalah etis, persoalan penguasaan kompetensi akuntansi terhitung masih minim terutama bagi akuntan yang baru menyelesaikan studinya di perguruan tinggi. Oleh sebab itu, pondasi dasar untuk memahami akuntansi perlu ditekankan pada mahasiswa, pondasi tersebut salah satunya adalah mata kuliah pengantar akuntansi. Fenomena ini terjadi pada mahasiswa jurusan akuntansi fakultas ekonomi Universitas PGRI Adi Buana Surabaya (Unipa) di mana penguasaan materi mata kuliah pengantar akuntansi masih tergolong rendah. Berdasarkan penelusuran diketahui bahwa jumlah mahasiswa yang memperoleh nilai A dalam beberapa mata kuliah pengantar akuntansi rata-rata tidak lebih dari 33,75\% dari total 227 mahasiswa untuk Jurusan Akuntansi. Ini berarti bahwa lebih sedikit (kurang dari 50\%) persentase mahasiswa yang memiliki tingkat pemahaman akuntansi maksimal (nilai A). Padahal, Jurusan Akuntansi Fakultas Ekonomi Unipa telah menerapkan kurikulum terbaru yang menerapkan proses pembelajaran dengan strategi dan metode pembelajaran terkini.

Ada beberapa hasil penelitian yang menjelaskan keterpengaruhan antara variabel pengetahuan awal akuntansi, efikasi diri, dan minat belajar akuntansi terhadap tingkat pemahaman akuntansi mahasiswa. Hasil penelitian Mahan (2007) menyebutkan bahwa selain strategi pembelajaran yang digunakan, pengetahuan awal juga turut membentuk tinggi-rendahnya tingkat pemahaman akuntansi mahasiswa. Campbell (2013) melakukan penelitian pada mahasiswa dan disebutkan bahwa ada 3 tipe umpan balik dari mahasiswa yang dihasilkan dari pengaruh level rendah dan level tinggi dari pemahaman awal (pengetahuan dalam merespon, pengetahuan dalam merespon dengan benar, dan elaboratif) akan memberikan dampak pada tinggi atau rendahnya minat belajar mahasiswa. Hayati (2007) dimana diperoleh hasil penelitian bahwa pengetahuan awal ditambah dengan sikap dan motivasi akan menghasilkan minat mahasiswa. Mukhid (2012) menemukan adanya perbedaaan hasil belajar pamahaman konsep metodologi penelitian antara kelompok belajar yang memiliki efikasi diri rendah dibanding dengan kelompok yang memiliki efikasi diri yang tinggi. Cheng dan Chiou (2010) yang menjelaskan dalam hasil penelitiannya bahwa Self efficacy dan atribusi memiliki pengaruh terhadap kecakapan hidup lulusan perguruan tinggi yang dihasilkan dari pemahaman yang dimiliki mahasiswa. Irwansyah (2013) pada mahasiswa reguler Prodi Pendidikan Akuntansi Jurusan Pendidikan Ekonomi Universitas Pendidikan Ganesa angkatan tahun 2009-2012 menjelaskan bahwa mahasiswa berminat untuk belajar akuntansi, dan hal ini berpengaruh terhadap tingkat pemahaman mereka.

\section{METODE PENELITIAN}

Pendekatan dalam penelitian ini adalah pendekatan kuantitatif. Berdasarkan variabel penelitian yang akan dikaji dan dianalisis hubungannya satu 
dengan yang lain, digunakan angket atau kuesioner. Teknik kuesioner dalam penelitian ini dipergunakan untuk mengumpulkan data tentang pengetahuan awal akuntansi, efikasi diri, minat belajar akuntansi, dan pemahaman akuntansi. Angket yang disebar telah valid dan reliabel. Penyebaran kuesioner dilakukan dengan mendatangi responden secara langsung dan berkoordinasi dengan instansi terkait dengan penelitian. Dalam hal ini penelitian dilakukan pada bulan Juni - Agustus 2015. Teknik analisis data yang digunakan adalah analisis deskriptif dan analisis Stuctural Equation Modelling (SEM). Sebelum dilakukan penggabungan model alternative terbaik, dilakukan uji unidimensionalitas konstruk tiap variabel dengan indikatornya kemudian digabungkan dengan variabel lainnya. Adapun rincian pengembangan Instrumen berikut ini:

1. Variabel Pengetahuan Awal Akuntansi (Prior Knowledge)

Untuk pengetahuan awal akuntansi terdiri dari 20 item pernyataan dengan 10 indikator. ini diambil dari hasil penelitian Brown (2005), Kujawa dan Huske (1995) dan Handayani (2014) tentang pengetahuan awal (prior knowledge) yang dalam hal ini disesuaikan dengan pengetahuan awal akuntansi. Adapun indikator tersebut adalah sebagai berikut: (1). Proses dan Konten Belajar, (2). Tujuan Pembelajaran, (3). Tujuan pribadi mahasiswa, (4). Memiliki keyakinan diri, (5). Kesadaran pada minat diri, (6). Memiliki kekuatan diri, (7). Memiliki motivasi diri, (8). Aktivitas yang dilakukan mahasiswa, (9). Pengalaman di lingkungan keluarga, dan (10). Pengalaman di lingkungan teman sebaya.

2. Efikasi Diri (Self Eficacy)

Untuk variabel efikasi diri terdiri 20 item pernyataaan dengan 7 indikator. Tingkat efikasi diri diambil dari penelitian yang telah dilakukan oleh Bandura (1997) dan Istibsyaroh (2013) terdiri dari (1). Mahasiswa yakin mampu memahami materi yang sulit, (2). Mahasiswa yakin mampu mengatasi hambatan dalam tingkat kesulitan tugas yang dihadapinya, (3). Mahasiswa berminat pada materi pembelajaran akuntansi, (4). Mahasiswa yakin memiliki kemampuan dalam berbagai macam tugas, (5). Mahasiswa yakin bahwa usaha yang dilakukan dapat mencapai tujuan dan tuntunan yang harus dicapai, (6). Mahasiswa mampu memecahkan masalah, (7). Mahasiswa yakin pengalaman buruk tidak akan menghalangi pencapaian keberhasilan, (8). Mahasiswa yakin mampu mengerjakan tugas dalam berbagai situasi dan kondisi, dan (9). Mahasiswa yakin mampu menyelesaikan tugas dengan tuntas.

3. Minat Belajar Akuntansi

Untuk variabel minat belajar akuntansi terdiri 20 item pernyataan dengan 7 indikator yang diambil dari Watoyo (2008) dan Slameto (2010) terdiri dari (1). Motivasi atau dorongan mahasiswa untuk belajar mata kuliah pengantar akuntansi (2). Partisipasi mahasiswa dalam kegiatan belajar mengajar akuntansi atau kegiatan lainnya, (3). Perhatian mahasiswa dalam kegiatan belajar mengajar, (4). Kesadaran mahasiswa sebagai subyek pembelajaran, (5). Perasaaan suka terhadap materi perkuliahan pengantar akuntansi, (6). Perasaan suka terhadap situasi belajar akuntansi, (7). Perasaan suka terhadap aktivitas belajar akuntansi. 
4. Tingkat Pemahaman Akuntansi

Untuk variabel pemahaman akuntansi terdiri dari 30 item pernyataan dengan tiga indikator yang diambil dari Mawardi (2011), dan Sar'i, dkk (2010). Adapun indikator ini adalah: (1) Pemahaman tentang aset, (2). Pemahaman tentang liabilitas dan (3). Pemahaman tentang ekuitas.

\section{HASILPENELITIAN DAN PEMBAHASAN}

Berdasarkan hasilpenelitian yang telah dilakukan bahwa deskripsi variabel penelitian didasarkan pada total jawaban responden yang telah ditentukan dari parameter teori sebagai standar pengukuran. Adapun hasil pengumpulan data responden bahwa pengetahuan awal mahasiwa yang sedang menempuh perkuliahan pengantar akuntansi di Universitas PGRI Adi Buana tergolong sangat tinggi $(3,85 \%)$, tinggi $(48,08 \%)$. sedang $(37,18 \%)$, rendah $(10,90 \%)$ dan tidak ada rata-rata tergolong sangat rendah. Terkait dengan efikasi diri mahasiswa, terbukti dengan prosentase kategori sangat tinggi $(3,21 \%)$, tinggi $(36,54 \%)$, sedang $(54,49 \%)$, rendah $(5,77 \%)$ dan tidak ada responden yang tergolong sangat rendah. Terkait dengan minat belajar akuntansi mahasiswa, dengan kategori sangat tinggi $(7,69 \%)$, tinggi $(57,05 \%)$, sedang $(35,26 \%)$, dan tidak ada responden yang tergolong minat rendah dan sangat rendah. Terkait penilaian tingkat pemahaman akuntansi mahasiswa dengan kategori sangat tinggi (2,56\%),tinggi $(39,10 \%)$, sedang $(53,21 \%)$, rendah $(5,13 \%)$ dan tidak ada responden yang tergolong pemahaman akuntansi dengan kategori sangat rendah.

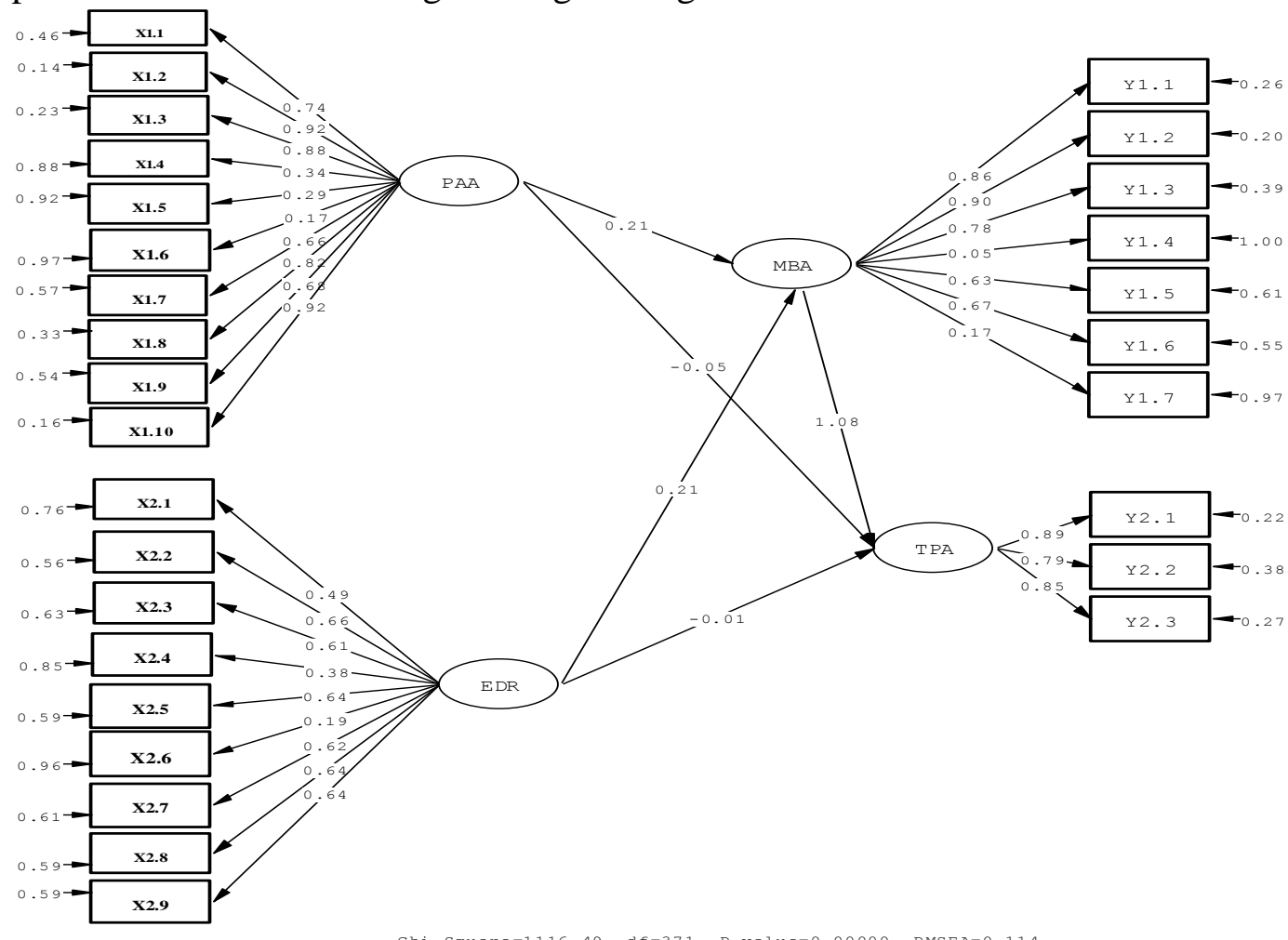

Gambar 1. Model Konseptual Penelitian (Model Awal)

Berdasarkan hasil analisis data yang telah dilakukan, bahwa semua data variabel tergolong normal, bebas multikolinearitas, dan bebas outlier. Ketika 
semua data sudah sesuai dengan persyaratan uji asumsi klasik, maka dilakukanlah uji unidimensiolitas konstruk kemudian digabungkan dalam model konseptual awal penelitian untuk mengetahui tingkat keselarasan model awal penelitian. Berikut adalah gambar 1. hasil uji model awal penelitian sebelum dilakukan perbaikan model.

Berdasarkan pada gambar 1. diatas disimpulkan bahwa ada beberapa koefisien lambda atau faktor loading indikator dari variabelyang tidak valid/ tidak memenuhi persyaratan sehingga perlu dihapus dari model penelitian. Selain itu, koefisien besaran-besaran yang menjadi persyaratan keselarasan model, dapat dikatakan tidak terpenuhi. Hal tersebut dapat dilihat pada tabel 1. berikut ini:

Tabel 1. Keselarasan Model Struktural Penelitian (Model Awal)

\begin{tabular}{|l|c|l|l|}
\hline \multicolumn{1}{|c|}{ Keselarasan Model } & Koefisien & \multicolumn{1}{c|}{ Kriteria } & Kesimpulan \\
\hline Chi-square $\left(X^{2}\right)$ & $1.116,49$ & Kecil (non signifikan) & Tidak terpenuhi \\
\hline$P$ - Value & 0,00 & $\geq 0,05$ & Tidak terpenuhi \\
\hline Df & 371 & \multicolumn{1}{c|}{--} & --- \\
\hline Cmin $\left(X^{2} / \mathrm{Df}\right)$ & 3,009 & $\leq 2,00$ & Tidak terpenuhi \\
\hline RMR (standardized) & 0,22 & $\leq 0,08$ & Tidak terpenuhi \\
\hline RMSEA & 0,11 & $\leq 0,08$ & Tidak terpenuhi \\
\hline GFI & 0,67 & $\geq 0,90$ & Tidak terpenuhi \\
\hline AGFI & 0,61 & $\geq 0,90$ & Tidak terpenuhi \\
\hline CFI & 0,81 & $\geq 0,94$ & Marginal \\
\hline IFI & 0,81 & $\geq 0,94$ & Marginal \\
\hline NNFI & 0,79 & $\geq 0,94$ & Tidak terpenuhi \\
\hline AIC / Model & 1244,49 & Kecil, Relatif & Tidak terpenuhi \\
\hline
\end{tabular}

(Sumber: Output Lisrel Model Awal Penelitian, 2015)



Gambar 2. Model Alternatif Terbaik

Tabel 1. di atas menunjukkan bahwa terdapat banyak persyaratan keselarasan model yang belum terpenuhi dikarenakan ada uji keselarasan tidak 
sesuai kriteria yang dipersyaratkan. Berdasarkan hal tersebut maka dapat dinyatakan bahwa model awal secara empiris ternyata belum memenuhi persyaratan uji model keselarasan. Selanjutnya berdasarkan hasil analisis pengujian model awal, dapat dilakukan modifikasi model, sehingga diperoleh model empiris yang memenuhi syarat keselarasan model. Berikut adalah hasil pengolahan data hasil modifikasi model terbaik penelitian dengan bantuan SEM Lisrell pada gambar 1.2. Nampak pada Gambar 1.2 di atas bahwa selain koefisien lambda atau faktor loading masing-masing manifes konstruknya valid, koefisien persamaan struktural yang menggambarkan tingkat pengaruh variabel eksogen terhadap variabel endogen juga signifikan. Meskipun demikian, keselarasan model perlu juga dilihat dari kecukupan besaran-besaran penentu tingkat keselarasannya dalam memenuhi kriteria, sesuai dengan ketetapan analisis model struktural. Hal tersebut dapat dilihat pada Tabel 1.2 berikut:

Tabel 2. Uji Keselarasan Model Alternatif Terbaik

\begin{tabular}{|l|c|c|l|}
\hline \multicolumn{1}{|c|}{ Keselarasan Model } & Koefisien & Kriteria & \multicolumn{1}{c|}{ Kesimpulan } \\
\hline Chy-square $\left(\mathrm{X}^{2}\right)$ & 171,20 & Kecil (non signifikan) & Baik, terpenuhi \\
\hline P- Value & 0,14 & $\geq 0,05$ & Baik, Terpenuhi \\
\hline Df & 160 & --- & --- \\
\hline Cmin $\left(\mathrm{X}^{2} / \mathrm{Df}\right.$ & 1,07 & $\leq 2,00$ & Baik, terpenuhi \\
\hline RMR (standardized) & 0,063 & $\leq 0,08$ & Baik, terpenuhi \\
\hline RMSEA & 0,021 & $\leq 0,08$ & Baik, terpenuhi \\
\hline GFI & 0,90 & $\geq 0,90$ & Baik, terpenuhi \\
\hline AGFI & 0,87 & $\geq 0,90$ & Marginal \\
\hline CFI & 0,99 & $\geq 0,94$ & Baik, terpenuhi \\
\hline IFI & 0,99 & $\geq 0,94$ & Baik terpenuhi \\
\hline NNFI & 0,99 & $\geq 0,94$ & Baik, terpenuhi \\
\hline AIC / Model & 271,20 & ----- & ----- \\
\hline
\end{tabular}

(Sumber: Output Lisrel lampiran Model Alternatif Terbaik, 2015)

Nampak pada Tabel 1.2 diatas dapat disimpulkan bahwa model alternative terbaik penelitian memiliki tingkat keselarasan model terbukti dengan semua sesuai dengan kriteria yang dipersyaratkan walaupun nilai AGFI dengan kategori sedang/ moderat. Wijanto (2008: 155) menyatakan bahwa tidak ada satu ukuran GOF yang secara ekslusif dapat mewakili kecocokan keseluruhan model, maka para peneliti akan berhenti melakukan perbaikan kecocokan keseluruhan model setelah banyak ukuran GOF yang menunjukkan kecocokan keseluruhan model yang baik. Dengan demikian, data hasil model temuan penelitian sudah dapat dimaknai telah memenuhi persyaratan keseluruhan dengan data.

Berdasarkan output model alternative terbaik diatas, persamaan model struktural alternatif terbaik adalah sebagai berikut:

Persamaan $1:$ MBA $=0.20 *$ PAA $+0.22 * E D R$, Errorvar. $=0.89, \mathbf{R}^{2}=0,11$

Persamaan $2:$ TPA $=1.00 *$ MBA, Errorvar $=0.0074, \mathbf{R}^{2}=0,99$

(Sumber: Output Lisrel lampiran Model Alternatif Terbaik, 2015)

Selanjutnya dari persamaan model struktural alternatif terbaik diatas, dapat pula dihitung pengaruh simultan antara pengetahuan awal akuntansi (PAA), efikasi diri (EDR) dan minat belajar akuntansi (MBA) terhadap tingkat pemahaman akuntansi (TPA) dengan menggunakan rumus sebagai berikut:

$$
\begin{aligned}
& \mathbf{R}^{2}=1-\left(0,89^{2} \times 0,01^{2}\right) \\
& \mathbf{R}^{2}=1-(0,792 \times 0,001)
\end{aligned}
$$


$\mathbf{R}^{2}=1-0,0009$

$\mathbf{R}^{2}=0,99$

Berdasarkan hasil perhitungan diatas, maka dapat dijelaskan bahwa PAA, EDR, dan MBA secara bersama-sama berpengaruh terhadap TPA sebesar 99\%.

Hasil temuan penelitian untuk menjawab hipotesis koefisien pengaruh langsung, tidak langsung, dan pengaruh secara simultan antar variabel dapat diringkas dengan Tabel 3. sebagai berikut:

Tabel 3. Pengaruh langsung, Tidak langsung, dan Simultan

\begin{tabular}{|c|c|c|c|c|c|c|c|}
\hline \multirow{3}{*}{ No. } & \multirow{3}{*}{ Pengujian } & \multicolumn{5}{|c|}{ Koefisien Pengaruh } & \multirow{3}{*}{ Kesimpulan } \\
\hline & & \multicolumn{2}{|c|}{ Langsung } & \multicolumn{2}{|c|}{ Tidak Langsung } & \multirow{2}{*}{$\begin{array}{c}\text { Simultan } \\
\text { (koefisien } \\
\mathbf{R}^{2)} \\
\end{array}$} & \\
\hline & & $\gamma, \beta$ & T-Value & $\gamma, \beta$ & T-Value & & \\
\hline 1. & PAA-TPA & - & - & - & - & - & Tidak Signifikan \\
\hline 2. & PAA - MBA & 0,20 & 2,38 & - & - & - & Signifikan \\
\hline 3. & EDR - TPA & - & - & - & - & - & Tidak Signifikan \\
\hline 4. & EDR - MBA & 0,22 & 2,55 & - & - & - & Signifikan \\
\hline 5. & MBA - TPA & 1,00 & 15,06 & - & - & - & Signifikan \\
\hline 6. & $\begin{array}{l}\text { PAA - TPA } \\
\text { (Melalui MBA) }\end{array}$ & 0,20 & 2,40 & - & - & - & Signifikan \\
\hline 7. & $\begin{array}{l}\text { EDR - TPA } \\
\text { melalui MBA) }\end{array}$ & 0,22 & 2,57 & - & - & - & Signifikan \\
\hline 8. & $\begin{array}{l}\text { PAA, EDR, } \\
\text { MBA - TPA } \\
\text { (Simultan) }\end{array}$ & - & - & - & - & 0,99 & Signifikan \\
\hline
\end{tabular}

Sumber: Diolah Peneliti (2015)

Hasil temuan penelitian menunjukkan bahwa pengetahuan awal akuntansi tidak berpengaruh positif signifikan terhadap tingkat pemahaman akuntansi pada mahasiswa jurusan akuntansi Universitas PGRI Adi Buana Surabaya. Berarti bahwa semakin tinggi pengetahuan awal mahasiswa tidak mempengaruhi tingginya tingkat pemahaman akuntansi mahasiswa. Hal ini tidak sesuai dengan hasil penelitian yang dilakukan oleh Mahan (2007) dalam sebuah disertasi doktoral di Universitas Negeri Pennsylvania yang menyebutkan bahwa selain strategi pembelajaran yang digunakan, pengetahuan awal juga turut membentuk tinggi-rendahnya tingkat pemahaman akuntansi mahasiswa. Sehingga dapat disimpulkan bahwa penggunaan strategi pembelajaran yang tepat dan didukung pengetahuan awal yang mencukupi akan membentuk pemahaman mahasiswa tentang materi akuntansi yang tinggi pula. Akan tetapi, secara empiris hasil penelitian ini menunjukkan hasil yang berbeda ketika penelitian di Universitas PGRI Adi Buana, dimana pengetahuan awal akuntansi tidak berpengaruh terhadap tingkat pemahaman akuntansi mahasiswa di Universitas PGRI Adi Buana Surabaya, maka kemungkinannya pengalaman dalam pembelajaran akuntansi diperguruan tinggi tidak ada kaitannya dengan pengetahuan awal mahasiswa tersebut.

Hasil temuan penelitian membuktikan bahwa pengetahuan awal akuntansi berpengaruh positif signifikan terhadap minat belajar mahasiswa. Hal ini dapat dimaknai bahwa pengetahuan awal akuntansi dalam mata kuliah pengantar akuntansi yang diberikan oleh dosen akuntansi bermakna bagi minat belajar mahasiswa akuntansi Universitas PGRI Adi Buana Surabaya. Artinya, semakin tinggi pengetahuan awal akuntansi, maka semakin tinggi pula minat belajar 
mahasiswa dalam mengikuti kegiatan perkuliahan pengantar akuntansi. Hasil penelitian ini sesuai dengan hasil disertasi doktoral Universitas Negeri Idaho yang dilakukan oleh Campbell (2013) yang menyebutkan bahwa ada 3 tipe umpan balik dari mahasiswa yang dihasilkan dari pengaruh level rendah dan level tinggi dari pemahaman awal (pengetahuan dalam merespon, pengetahuan dalam merespon dengan benar, dan elaboratif) akan memberikan dampak pada tinggi atau rendahnya minat belajar mahasiswa. Pengetahuan awal mahasiswa jurusan akuntansi Universitas PGRI Adi Buana Surabaya tergolong cukup tinggi. Hal ini berarti tergantung peran dosen akuntansi untuk memberikan dorongan agar minat belajar mahasiswa dapat semakin tinggi.

Hasil temuan penelitian menunjukkan bahwa efikasi diri tidak berpengaruh positif signifikan terhadap tingkat pemahaman akuntansi pada mahasiswa akuntansi di Universitas PGRI Adi Buana Surabaya. Hal ini berarti semakin tinggi efikasi diri mahasiswa maka tidak mempengaruhi tingginya tingkat pemahaman akuntansi pada mahasiswa jurusan akuntansi Universitas PGRI Adi Buana Surabaya. Hasil penelitian tersebut berbeda dengan hasil penelitian yang dilakukan oleh Cheng dan Chiou (2010) yang menjelaskan dalam hasil penelitiannya bahwa Self efficacy dan atribusi memiliki pengaruh terhadap kecakapan hidup lulusan perguruan tinggi yang dihasilkan dari pemahaman yang dimiliki mahasiswa. Berdasarkan analisis peneliti, penyebab tidak terpengaruhnya efikasi diri terhadap tingkat pemahaman akuntansi pada mahasiswa jurusan akuntansi Universitas PGRI Adi Buana Surabaya yang pertama adalah bisa juga sama kasusnya dengan hasil penelitian Budiadi dan Sulistyawati (2013) bahwa self efficacy tidak berpengaruh secara signifikan parsial terhadap tingkat pemahaman akuntansi mahasiswa di Kediri pada mata kuliah Akuntansi. Kepercayaan diri yang dimiliki mahasiswa dinilai masih kurang sehingga dalam menjalankan aktivitas perkuliahan tidak bisa memperoleh hasil maksimal dibanding dengan mahasiswa yang memiliki efikasi diri yang tinggi. Selain faktor tersebut, bisa juga mahasiswa akuntansi belum dihadapkan dalam situasi yang benar-benar riil, sehingga mereka belum dapat memahami situasi yang dihadapi dan kemudian membuat suatu penilaian secara tepat apakah dia sanggunp untuk melakukan suatu tugas atau tidak. Pada saat masih menempuh pendidikan, jika mahasiswa tidak diarahkan untuk meningkatkan kepercayaan diri bisa saja terpengaruh oleh faktor-faktor eksternal yang lain sehingga akan menganggap dirinya belum mampu untuk menghadapi suatu masalah.

Hasil temuan penelitian menunjukkan bahwa efikasi diri berpengaruh positif signifikan terhadap minat belajar akuntansi pada mahasiswa jurusan akuntansi Universitas PGRI Adi Buana Surabaya. Berarti bahwa semakin tinggi efikasi diri maka semakin tinggi pula minat belajar akuntansi. Sebaliknya efikasi diri mahasiswa yang rendah berpengaruh terhadap minat belajar akuntansi yang rendah pula. Berdasarkan kajian teoritis yaitu menurut Bandura (1997) bahwa efikasi diri adalah pertimbangan subjektif individu terhadap kemampuannya untuk menyusun tindakan yang dibutuhkan untuk menyelesaikan tugas-tugas khusus yang dihadapi seseorang. Mahasiswa memiliki efikasi diri yang rendah selalu berusaha untuk menghindari kesalahan dan tidak percaya dengan kemampuannya sendiri. Mahasiswa yang memiliki efikasi diri akan menimbulkan minat dalam sesuatu hal yang diinginkannya. Hasil penelitian ini sesuai dengan hasil penelitian Bandura (1997) dan Istibsyaroh (2013), bahwa efikasi diri 
berpengaruh positif terhadap minat belajar akuntansi. Penelitian tersebut juga didukung oleh penelitian Rokhimah (2015) efikasi diri mempengaruhi minat seseorang dan besarnya usaha yang akan dilakukan. Pada subjek penelitian di sekolah, pengaruh efikasi diri terhadap minat dapat dilihat dari penelitian tesis yang dilakukan oleh Hidayah (2012) di dalam penelitiannya disebutkan bahwa self efikasi memengaruhi minat siswa.

Hasil temuan penelitian menunjukkan bahwa minat belajar akuntansi berpengaruh signifikan terhadap tingkat pemahaman akuntansi pada mahasiswa jurusan akuntansi Universitas PGRI Adi Buana Surabaya. Berarti bahwa semakin tinggi minat belajar akuntansi maka menyebabkan perubahan pada tingkat pemahaman akuntansi pada mahasiswa akuntansi Universitas PGRI Adi Buana Surabaya. Sebaliknya mahasiswa yang mempunyai minat belajar akuntansi yang rendah pun membawa pengaruh terhadap besar-kecilnya tingkat pemahaman akuntansi mahasiswa. Berdasarkan kajian teoritis Slameto (2010) bahwa minat adalah suatu rasa lebih suka dan rasa ketertarikan pada suatu hal atau aktivitas, tanpa ada yang menyuruh. Begitu pula dengan pendapat Aiken (2009) bahwa dasarnya minat adalah kesukaan terhadap sesuatu yang berjalan seiring waktu sehingga dapat berjalan dengan baik dan terarah pada kegiatan yang merupakan suatu hal yang menjadi hobi seseorang tersebut. Stiggins (2004) bahwa minat adalah aspek afektif yang banyak berperan dalam kehidupan seseorang yang mengidentifikasi dimensi-dimensi perasaan dari kesadaran emosi, disposisi, dan kehendak yang mempengaruhi pikiran dan tindakan seseorang. Ketika seseorang berminat maka dia akan melakukan tindakan untuk berbuat sesuatu. Sama halnya dengan ketika mahasiswa memiliki minat untuk belajar akuntansi maka dia akan bertindak untuk bisa paham dengan materi akuntansi. Hasil penelitian ini sesuai dengan hasil penelitian Irwansyah (2013) pada mahasiswa reguler Prodi Pendidikan Akuntansi Jurusan Pendidikan Ekonomi Universitas Pendidikan Ganesa angkatan tahun 2009-2012 yang menghasilkan kesimpulan bahwa minat belajar mahasiswa terhadap materi akuntansi berpengaruh terhadap tingkat pemahaman akuntansi mereka. Penelitian tersebut juga didukung oleh penelitian Yorika, dkk (2013) bahwa minat belajar juga memiliki pengaruh terhadap pemahaman akuntansi dilihat dari t hitung $(2,449)>t$ tabel $(1,984)$ dengan signifikasi $0,000(<0,05)$. Sejalan dengan hal tersebut, hasil penelitian Evytasari (2010) juga menghasilkan hal yang sama yaitu minat belajar mempunyai pengaruh signifikan terhadap tingkat pemahaman akuntansi pada mahasiswa UPN "Veteran" Jawa Timur. Hasil temuan penelitian menunjukkan bahwa pengetahuan awal berpengaruh positif signifikan secara tidak langsung terhadap tingkat pemahaman akuntansi melalui minat belajar mahasiswa jurusan akuntansi di Universitas PGRI Adi Buana Surabaya. Berdasarkan hasil penelitian bahwa tingkat pengetahuan awal akuntansi mahasiswa Akuntansi di Universitas PGRI Adi Buana Surabaya dalam tingkatan tinggi, minat belajar juga tergolong tinggi. Sedangkan tingkat pemahaman akuntansi mahasiswa tergolong sedang. Hal ini dapat dijelaskan bahwa dengan adanya pengetahuan awal yang tinggi tentang materi akuntansi yang sudah didapatkan mahasiswa akan berpengaruh terhadap minat yang tinggi dalam belajar akuntansi. Sementara minat yang tinggi maka akan mempengaruhi mahasiswa akuntansi untuk paham terhadap materi akuntansi. Secara tidak langsung maka pengetahuan awal yang dimiliki oleh 
mahasiswa akan berpengaruh terhadap tingkat pemahaman akuntansi mahasiswa melalui minat belajar akuntansi yang tinggi.

Hasil temuan penelitian menunjukkan bahwa efikasi diri mahasiswa berpengaruh positif signifikan secara tidak langsung melalui minat belajar terhadap tingkat pemahaman akuntansi pada mahasiswa jurusan akuntansi di Universitas PGRI Adi Buana Surabaya. Pada hasil analisis data tingkat efikasi diri mahasiswa di Universitas PGRI Adi Buana Surabaya dikategorikan sedang, sedangkan minat belajar dikategorikan tinggi, dan tingkat pemahaman akuntansi mahasiswa juga dengan kategori tinggi. Hal ini dapat dijelaskan bahwa dengan adanya efikasi yang dimiliki oeh mahasiswa akan berpengaruh terhadap minat mahasiswa dalam belajar akuntansi. Sementara itu, minat yang tinggi maka akan mempengaruhi mahasiswa akuntansi untuk paham terhadap materi akuntansi. Secara tidak langsung maka efikasi diri yang dimiliki oleh mahasiswa akan berpengaruh terhadap tingkat pemahaman akuntansi mahasiswa melalui minat belajar akuntansi.

Hasil temuan penelitian menunjukkan bahwa pengetahuan awal akuntansi, efikasi diri, dan minat belajar berpengaruh simultan positif signifikan terhadap tingkat pemahaman belajar mata kuliah pengantar akuntansi mahasiswa jurusan akuntansi di Universitas PGRI Adi Buana Surabaya. Hal ini dapat dibuktikan dengan hasil model terbaik penelitian bahwa variabel pengetahuan awal, efikasi diri, dan minat belajar sesuai dengan tingkat keselarasan model yang menyatu dan konverge sehingga membentuk suatu keterpengaruhan terhadap variabel tingkat pemahaman akuntansi. Selain itu hasil model persamaan structural dengan nilai $\mathrm{R}^{2}$ sebesar $99 \%$ dipengaruhi oleh pengetahuan awal, efikasi diri dan minat belajar akuntansi. Sedangkan 1\% dipengaruhi oleh variabel lainnya diluar penelitian. Hasil temuan penelitian mendukung hasil kajian teoritis dan empiris terdahulu dan membuktikan bahwa variabel yang mempengaruhi tingkat pemahaman akuntansi diantaranya adalah pengetahuan awal akuntansi, efikasi diri dan minat belajar akuntansi.

\section{SIMPULAN}

Berdasarkan pembahasan dan hasil analisis data yang dilakukan dalam penelitian ini dapat disimpulkan sebagai berikut: (1). Tidak terdapat pengaruh langsung positif signifikan pengetahuan awal akuntansi terhadap tingkat pemahaman akuntansi mahasiswa akuntansi Universitas PGRI Adibuana Surabaya, (2). Terdapat pengaruh langsung positif signifikan pengetahuan awal akuntansi terhadap minat belajar akuntansi mahasiswa akuntansi Universitas PGRI Adi Buana Surabaya,(3). Tidak terdapat pengaruh langsung positif signifikan efikasi diri terhadap tingkat pemahaman akuntansi mahasiswa akuntansi Universitas PGRI Adibuana Surabaya, (4). Terdapat pengaruh langsung positif signifikan efikasi diri terhadap minat belajar akuntansi mahasiswa akuntansi Universitas PGRI Adi Buana Surabaya, (5). Terdapat pengaruh langsung positif signifikan minat belajar akuntansi terhadap tingkat pemahaman akuntansi mahasiswa akuntansi Universitas PGRI Adi Buana Surabaya, (6). Terdapat pengaruh tidak langsung positif signifikan pengetahuan awal akuntansi terhadap tingkat pemahaman akuntansi melalui minat belajar akuntansi Mahasiswa Akuntansi Universitas PGRI Adi Buana Surabaya, (7). Terdapat 
pengaruh tidak langsung positif signifikan efikasi diri terhadap tingkat pemahaman akuntansi melalui minat belajar akuntansi mahasiswa Akuntansi Universitas PGRI Adi Buana Surabaya, (8). Terdapat pengaruh simultan positif signifikan pengetahuan awal akuntansi, efikasi diri dan minat belajar akuntansi terhadap tingkat pemahaman akuntansi Mahasiswa Akuntansi Universitas PGRI Adibuana Surabaya.

Berdasarkan pada temuan penelitian diajukan saran sebagai berikut: (1). Dosen akuntansi perlu tetap memperhatikan kombinasi penggunaan berbagai materi, metode, media, dan proses pengetahuan awal akuntansi karena hal ini dapat membuat pengetahuan awal akuntansi mengena dan dipahami secara mudah dan cepat; (2). Jurusan akuntansi perlu melakukan dan meninjau ulang mengenai kualitas mahasiswa dan kualitas dosen serta kualitas pembelajaran selama diperkuliahan agar bisa meningkatkan pengetahuan awal, efikasi diri, minat dan pemahaman akuntansi mahasiswa, (3). Untuk penelitian selanjutnya disarankan menambah sampel penelitian, menambah kasus-kasus yang lebih ekstrim dalam kuesioner, dan menambah faktor-faktor lain yang lebih berpengaruh terhadap tingkat pemahaman akuntansi mahasiswa.

\section{DAFTAR RUJUKAN}

Adicondro, Nobelina dan Purnamasari Alfi. 2011. Efikasi Diri, Dukungan Sosial Keluarga dan Sefl Regulated Learning pada Mahasiswa Kelas VIII. Jurnal Humanitas. Vol. VIII. No. 01.

Aiken, Lewis R. Marnat, Gary Groth. 2009. Pengetesan dan Pemeriksaan Psikologi. Edisi ke dua belas. Jilid 2. Jakarta: Indeks.

Ariani, Rika. 2004. Persepsi Akuntan dan Mahasiswa Akuntansi Terhadap Karir di Kantor Akuntan Publik, (Skripsi tidak dipublikasikan). Universitas Bung Hatta, Padang.

Bandura, Albert. 1997. Self Efficacy The Exercise of Control, First Edition. Freeman: New York.

Brown, H. Douglas. 2005. Teaching by Principles An Interactive Approach to Language Pedagogy. New York: Longman.

Budiadi, Dwi dan Sulistyawati, Jenny (2013). Pengaruh Kompetensi Dosen, Self Efficacy, Lucos of Control, Fasilitas Pembelajaran Terhadap Tingkat Pemahaman Mahasiswa Akuntansi. Jurnal Cahaya Aktiva. Vol. 20 No. 1. Politeknik Cahaya Surya Kediri.

Campbell, Donald P. 2013. The Effect Of Prior Knowledge And Feedback Type Design On Student Achievement And Satisfaction In Introductory Accounting. A dissertation not publication. Idaho State University: ubmitted in partial fulfillment of the requirements for the degree of Doctor of Philosophy in Instructional Design.

Cheng, Pi-Yueh dan Chiou, Wen Bin. 2010. Achievement, Attributions, SelfEfficacy, And Goal Setting By Accounting Undergraduates. Review of Journal Psychological Reports, Vol. 106, pp 1-11. Institute of Education National Sun Yat-Sen University.

Djamarah, Shaiful Bahri. 2002. Guru dan Anak dalam Interaksi Edukasi. Jakarta: Rineka Cipta. 
Dwirandra. 2013. Pengaruh Perilaku Belajar terhadap Tingkat Pemahaman Akuntansi dan Sikap Etis dengan Kecerdasan Emosional dan Kecerdasan Spiritual sebagai Variabel Pemoderasi. (Tesis tidak dipublikasikan). Universitas Udayana.

Evytasari, Aditya Anggraeni. 2010. Pengaruh Pengendalian Diri, Motivasi Dan Minat Belajar Terhadap Tingkat Pemahaman Akuntansi (Studi Kasus Pada Mahasiswa Akuntansi Upn "Veteran" Jawa Timur). (Tesis yang tidak dipublikasikan). Universitas UPN "Veteran"

Handayani, Veronika Tri. 2014. Pengetahuan Awal, Kedisiplinan Belajar, dan Iklim Komunikasi di Kelas Berpengaruh pada Hasil Belajar Produktif Akuntansi Mahasiswa Kelas XI Jurusan Akuntansi SMK Negeri 3 Bangkalan. (Tesis tidak dipublikasikan). Universitas Negeri Surabaya.

Hariyoga, Septian dan Suprianto, Edy. 2011. Pengaruh Kecerdasan Emosional, Perilaku Relajar, dan Budaza Terhadap Tingkat Pemahaman Akuntansi Dengan Kepercayaan Diri sebagai Variable Pemoderasi.Simposium Nasional Akuntansi. XIV.

Hayati, Rahmah Nur. 2007. Pengaruh Pengetahuan, Sikap, dan Motivasi Terhadap Minat Bidan untuk Mengikuti Uji Kompetensi di Kota Semarang Tahun 2007. (Tesis tidak dipublikasikan). Universitas Diponegoro Semarang.

Hidayah, Noor. 2012. Pengaruh self-efficacy, latar belakang orang tua dan prestasi belajar terhadap minat siswa smk berwirausaha bidang agronomi di kabupaten tanah bumbu. (Tesis tidak dipublikasikan). Universitas Negeri Yogyakarta: Program Studi Pendidikan Teknologi dan Kejuruan.

Indriyanti, Ninuk., Siswandari dan Elvia Ivada. 2013. Faktor - Faktor Yang Mempengaruhi Minat Melanjutkan Pendidikan ke Perguruan Tinggi pada Siswa Kelas XII Akuntansi SMK Negeri 6 Surakarta tahun 2013. Jupe UNS, Vol. 1, No. 2, Hal 1 s/d 10

Irwansyah, Rudi. 2013. Pengaruh Hasil Belajar Dasar-Dasar Akuntansi, Matematika Ekonomi-Bisnis, dan Minat Belajar Terhadap Pemahaman Akuntansi yang Dikategorikan Berdasarkan Gaya Belajar. Jurnal Pendidikan Ekonomi. ISSN 1829-5282. Universitas Pendidikan Ganesha.

Istibsyaroh, Anis. 2013. Pengaruh keyakinan diri dan pengetahuan awal terhadap minat belajar materi akuntansi kelas XII SMP Negeri di Kota Mojokerto. (Tesis tidak dipublikasikan). Universitas Negeri Surabaya.

Kujawa dan Huske. (2003). Critical Issue: Building on Prior Knowledge and Meaningfull Student Contexs/Curltures. http://www.nerel.org. Diakses pada tanggal 20 Mei 2015.

Mahan, Wendy L. 2007. Effect Of Prior Knowledge And Principle-Based And Procedure-Based Instructional Strategies On Students' Transfer Of Principles. Dissertation not publication.

Mawardi. M. Cholid. 2011.Tingkat Pemahaman Mahasiswa Akuntansi Terhadap Konsep Dasar Akuntansi di Perguruan Tinggi di Kota Malang. Jurnal Akuntansi Fakultas EkonomiUniversitasIslam (Unisma) Malang.

Mukhid, Abdul. 2012. Pengaruh Strategi Pembelajaran dan Tingkat Self-Efficacy terhadap Pemahaman Konsep dan Aplikasi Konsep Metodologi Penelitian. (Disertasi tidak dipublikasikan). Program Studi Teknologi Pembelajaran, Program Pascasarjana,Universitas Negeri Malang. 
Permendikbud Nomor 49. 2014. Standar Nasional Pendidikan Tinggi. Jakarta: Kemendikbud.

Rokhimah, Siti. 2015. Pengaruh Dukungan Sosial dan Efikasi Diri Terhadap Minat Melanjutkan Pendidikan ke Perguruan Tinggi Pada Siswa SMA Negeri 1 Tenggarong Seberang. E-Journal Psikologi. Vol.1 pp. 382-394. Universits Mulawarman.

Santyasa, I W. 2005. Model Pembelajaran Inovatif dalam Implementasi Kurikulum Berbasis Kompetensi. Makalah. Disajikan dalam Penataran Guru-Guru SMP, SMA, dan SMK se Kabupaten Jembrana, Juni - Juli 2005, di Jembrana.

Sar'i, Muhammad,Muhammad Irsadsyah, Nasrullah Djamil. 2010. Analisis Tingkat Pemahaman Mahasiswa Akuntansi Terhadap Konsep Dasar Akuntansi (Studi Empiris Pada Mahasiswa Akuntansi S1 UIN SUSKA Riau Yang Berasal Dari Latar Belakang Sekolah Menengah Yang Berbeda). Purwokerto: Simposium Nasional Akuntansi XIII. Vol 13.

Subroto, T. W. 2013. Analysis influence of teacher empowerment perfomance within improving the quality of education in elementary school in surabaya city. Journal of Economics and Suitable Development, 4, 2, 2222-2855.

Suhardian, Martha. 2012. Analisis dan Pengembangan Sistem Akuntansi Pendapatan pada Institusi Pendidikan: Studi kasus pada Universitas PGRI Adi Buana. Surabaya: Jurnal Akuntansi. Universitas PGRI Adi Buana.

Slameto. 2010. Belajar dan Faktor-Faktor yang Mempengaruhi. Jakarta: Rineka Ciepta.

Stiggins, R. J., 2004, Student Center Classroom Assesment, New York: Macmillan College Publishing Company

Suwardjono. 2001. Mamahamkan Akuntansi Dengan Penalaran dan Pendekatan Sistem. Jurnal Ekonomi dan Bisnis Indonesia, Vol. 14 No.3, pp.106-122.

Taylor, Shelley E. et al. (2009). Psikologi Sosial Edisi Kedua Belas. Jakarta: Kencana Prenada Media Group.

Watoyo, Dwi. 2008. Hubungan Antara Lingkungan Belajar dan Minat Belajar Siswa dengan Prestasi Belajar Mata Pelajaran Akuntansi Kelas XI Jurusan IPS SMAN 1 Paninggaran Kabupaten Pekalongan Tahun 2008. (Tesis tidak dipublikasikan). Universitas Sebelas Maret Surakarta.

Wijanto, Setyo Hari. 2008. Structural Equation Modeling dengan Lisrel 8.8. Kosep dan Tutorial. Yogyakarta: Graha Ilmu.

Yorika,Yolla, Azwir Nasir dan Nur Azlina. 2013. Pengaruh Kecerdasan Emosional, Kecerdasan Intelektual dan Minat Belajar Terhadap Tingkat Pemahaman Akuntansi. Jurnal Fokus Ekonomi.Vol. 5, pp 44-60. Fakultas Ekonomi Universitas Sultan Syarif Kasim Riau 